\title{
Strengthening National Identity to Younger Generation through Internalization of Pancasila Values in the Digital Era
}

\author{
Nur Fadhilah, Triyanto, Rukayah
}

\begin{abstract}
The existency of digital era has spread in all generation, especially the younger generation which is the next generation of the nation. National identity as the important part of a nation needs to be firmly embedded to the younger generation. The basic of national identity of Indonesia is Pancasila (five basic principles). This study aims to explain the process of strengthening the national identity to the younger generation through internalization of Pancasila values in the digital era and analyze the obstacles found during the process. The research subject was the youth club of Sidomulyo Village. The results of the study indicate that the process of strengthening the national identity to the younger generation is carried out through pro-social activities such as regular monthly meetings and blood donation events. Some of the obstacles encountered in the process are the differences of thinking and the difficult permit process. This research is expected to provide information and foundation in determining activities to strengthen the national identity of the younger generation in the digital era.
\end{abstract}

Index Terms: digital era; younger generation; national identity; Pancasila values

\section{INTRODUCTION}

Digital age is a life where humans use technology in most of their needs. The digital age was born with the emergence of digital, internet networks, especially computer information technology[20]. Information and communication technology has spread throughout life, such as the internet, smart phones, and social media[1]. Today, most of a person's life cannot be separated from an internet application called social media. Social media is a place where someone can make instant communication, express thoughts, and share them collectively through internet networks[2]. Social media itself can be categorized in two dimensions namely social presence and self presentation[7]. From these two dimensions, it should be able to improve prosocial attitudes for the community because it narrows the distance for people who find it difficult to communicate face-to-face.
Table I Percentage of Indonesian population by age (2018)

\begin{tabular}{lll}
\hline Age (year) & Total Population & Percentage(\%) \\
\hline $0-9$ & 47608100 & 17.96 \\
$\mathbf{1 0 - 1 9}$ & $\mathbf{4 5 1 2 1 6 0 0}$ & $\mathbf{1 7 . 0 2}$ \\
$\mathbf{2 0 - 2 9}$ & $\mathbf{4 2 9 4 8 6 0 0}$ & $\mathbf{1 6 . 2}$ \\
$\mathbf{3 0 - 3 9}$ & $\mathbf{4 0 7 0 9 7 0 0}$ & $\mathbf{1 5 . 3 6}$ \\
$40-49$ & 36520800 & 13.78 \\
$50-59$ & 27352000 & 10.32 \\
$60-69$ & 15718700 & 5.93 \\
$70+$ & 9035800 & 3.4 \\
\hline Total & 265015300 & 100 \\
\hline
\end{tabular}

Source: databooks.katadata.co.id

The booming technological development now brings social change[15], such as making social media as necessity, like status updates on Facebook and photos updates on Instagram to become a daily activity of young people[1]. A person is considered young if he is in the age range of 18-25 years[21], 18-34 years[17], and 12-34 years with 12-19 years as a teenager and 20-34 years as a young adult[11]. Table 1 shows that the number of young people in Indonesia reaches $48.59 \%$. Therefore, it can be assumed that almost half of Indonesian citizens live close to social media. The youth, who are comfortable with the use of social networking sites to communicate practically, tend to reduce face-to-face interpersonal interactions[3]. The decrease in face-to-face interaction, in a sense, can reduce the spirit of togetherness among one another. If the spirit of community togetherness decreases, later it can reduce humanist attitudes, an attitude which becomes one of the characteristics of the Indonesian nation, and results in an individualist attitude. This is clearly close to an anti-social attitude which ultimately can destroy the national identity of the Indonesian people.

\section{LITERATUR REVIEW}

National identity is closely related to one's emotions towards their social culture, political life in a country, and ideology[8]. Becoming aware of the original culture of the Indonesian nation, namely togetherness, is one reflection that the national identity does not fade or even become extinct. This is because the only strong support for the national identity of a nation is cultural traditions, especially national mentality and values[8] Therefore, it is necessary to

Nur Fadhilah, Magister of Primary Teacher Education, Sebelas Maret University, Surakarta, Indonesia.

Triyanto, Civic Education, Faculty of Teacher Training and Education, Sebelas Maret University, Surakarta, Indonesia.

Rukayah, Primary Teacher Education, Faculty of Teacher Training and Education, Surakarta, Indonesia. 
strengthen the national identity in youth to face the development of era in Indonesia today.

The Indonesian nation has formulated a basis or principle called Pancasila (The State Philosophy). Morfit states that there are five principles in Pancasila[6]. These five principles respectively are Belief in the One and only God, Fair and Civilized Humanity, Indonesian Unity, Democracy Guided by Inner Wisdom in the Unanimity Arising Out of Deliberations among Representatives, and Social Justice for the Entire Indonesian People. The five principles contain five great values, namely the divine values, human values, the value of unity, people's values, and the value of justice. Those five values must be used as a way of life in saying and acting as Indonesian citizens.

Pancasila will be able to filter out all the effects of globalization, and adapt it to the values contained therein[23]. In Pancasila, there are many values that cannot be separated from the lives of its citizens like the value of humanity that results in actions such as mutual help, mutual cooperation, and cooperation. It will continue to live if everyone does not merely have interaction with social media and is aware of the values of Pancasila in the surrounding environment. Pancasila socialization can be done at school and outside the school environment. Socialization in schools is done through Pancasila and Citizenship Education (PPKn) subjects. That can be one of the efforts to build defence for young children to face the global challenges of digital era today.

However, the environment of young children is not only at school, but also in the community. The youth community is usually gathered in an association called 'karang taruna' (the commmunity youth development). It is this youth that is the target of strengthening the national identity as a filter for globalization in the digital era today. [10] states that youth is a very important period for developing individuals as needed by society, in this case, developing youth in community life in accordance with the values of Pancasila.

This research aimed to find out what things are done by young people in karang taruna to strengthen national identity in the digital era and find out the obstacles in the process. The results of this research are expected to provide benefits for several groups both theoretically and practically. Theoretically, this research is expected to be able to support the theory of social engineering which essentially requires changes in attitudes and values of individuals to overcome a problem. Practically for writers, readers, and public, this subject of this research namely PPKn will be used to add knowledge to understand about national identity to be strengthened again as a reference in the life of the people and the nation.

\section{METHODS}

The research was conducted in karang taruna in a village named Sidomulyo, which is well-known as PRAM: The Youth Association of Active Development. Members of PRAM include 29 people in the age range of 13-34 years. All data were collected using qualitative assessment by means of semi-structured interviews, observation of active participation, and document analysis. Semi-structured interviews were submitted to: a) PRAM- person in charge who understands the ins and outs of the formation of karang taruna; b) the chairperson of the PRAM who understands every detail of the program of activities and the support and obstacles faced in the activity; c) several members of PRAM; and d) several representative residents to confirm each activity carried out by PRAM. Observation of active participation was done by participating in a PRAM monthly and annually routine activity and document analysis to support the data obtained in the form of regular monthly minutes, proposals, photos, and video activities. Data analysis used techniques from Milles \& Huberman namely data reduction, data presentation, and verification.

\section{RESULTS AND DISCUSSION}

The PRAM Karang Taruna has been established since 1991 with 15 initial members. The process of gathering members was done through word of mouth. For those who are interested in participating, without any selection, all members are accepted and immediately registered as members. The reason some members participated in PRAM's membership was to get more friends. At present, the number of PRAM members is 29 including the chairman, using the current technological developments with the evidence of smartphone use by each member at all karang taruna events.

Strengthening Pancasila values in PRAM Karang Taruna is included in the socio-cultural development path. This refers to the statement of[5] that there are three developmental approaches in the implementation of Pancasila socialization, among others the development of learning education (psycho-paedagogical development), socio-cultural development, and socio-political intervention. Participation in membership of karang taruna is the creation of a conducive social-cultural environment with the creation of interaction patterns, institutions and social-cultural institutions in the community.

Efforts to strengthen the national identity of the young generation through the internalization of Pancasila values can be seen from the activities carried out in karang taruna. These activities are described as follows:

\section{A. Regular Monthly Meetings}

This activity aims to discuss the implementation of an activity, meeting, and other activities for the benefits of karang taruna. This regular meeting is held on Saturday night on the first week of each month at 19.30 WIB until 21.00 WIB (Western Indonesian Time). The meeting takes place at the house of one of the PRAM members selected in the meeting place. This is so that each PRAM member knows more about other PRAM members. (Maarof, N. \& Tan, 2013)in their research states that a close interpersonal approach could encourage someone to be more active, in this case being active in youth organizations carried out in Sidomulyo village. The regular PRAM meeting is relevant to the implementation of the $4^{\text {th }}$ Pancasila principle so that it confirms that this activity can be an effort to strengthen Pancasila values through the implementation of deliberations to reach consensus. [16] suggests that 
deliberation can be controlled consciously. This routine meeting reflects the organization that applies democracy with its deliberations. Therefore, all PRAM members are included in each meeting, even though in deliberations, there are usually differences of opinion with each other [4]. If not all members are included, then the practice of democracy is not successful. Unsuccessful democracy can lead to disaster, such as anarchy and ignorance[14]. Thus, the activity of selecting a chairman in a class by including students is an effort to minimize ignorance and act of anarchy.

\section{B. Blood Donation}

Blood donation is a routine activity held by PRAM in collaboration with PMI (Indonesian Red Cross) which is usually carried out within once in 3 months. During the research, PRAM's blood donor activities were held precisely on Sunday 30 September 2018 at Sidomulyo Amanat House at 09.00 WIB until 10.00 WIB. Blood donation activity is a manifestation of the second principle of Pancasila by implementing human values in the protection of the survival of individuals. Through this activity, a sense of mutual respect will be embedded between human beings and respect for the meaning of their fellow life. If the level of appreciation to humans is low, it will increase group differentiation[12]. Therefore, participating in blood donor activities is one of the efforts to minimize social differentiation in the community through youth organizations.

\section{Marking the Perforated Road}

The activity of marking a perforated road or a damaged road is one of PRAM's activities in collaboration with the Volunteer Community of Sidomulyo Village or commonly known as RDS held at the end of April until mid-May 2018. The activity of marking the perforated road are held every Tuesday afternoon. This activity is one manifestation of the fifth principle of Pancasila by carrying out an activity that can support equitable development. If the distribution of resources is unfair, it will create inequality, and inequality can lead to social exclusion in various opportunities, even in voluntary social exclusion [9].

This activity is not only intended so that people can avoid damaged roads but also as a form of criticism and notification to the local government that there are roads that must be repaired immediately. According to Katz and Lazarsfeld (1955), certain people are recognized as leaders in an opinion that can interpret information and convey it to others[19]. In this case, PRAM is like a forum to interpret and convey information to the authorities for damage to existing roads in the hope that the government is quick to respond immediately to repair the damaged road.

All PRAM activities in order to strengthen the national identity are always done through participation because PRAM is purely derived from heterogeneous elements of society. PRAM activities involve citizens as members and non-members to participate in community activities. Participation as a member of PRAM is significant for the success of programs or activities carried out in order to produce goodness for each executive and every member as an individual. The participation of PRAM members to strengthen the national identity is a manifestation of civic skills. There are two skills that every citizen must have in Civic skills which include intellectual skills and participation skills. If related to this, the actions taken in PRAM activities are a form of participation skills where members and citizens are actively involved in PRAM programs.

Participation in Citizenship Education is included in one of the fields in the Four Basic Theories of Citizenship. The four basic theories of citizenship include Liberal Theory, Consensual Order, Participatory Republicanism, and Moderate Post-modern Plularism. Participation is included in Participatiry Republicanism which explains that "citizens participate in a tolerant and fair way in community councils and forums in order to establish a just society". This means that citizens participate in a tolerant and fair manner in the community and community forums to create a just society.

There are four types that indicate the stages of community participation, namely participation in decision making, participation in the implementation of activities, participation in monitoring and evaluation activities and participation in the utilization of development outcomes[22]. If it is related to the stages of participation, it can be explained that participation in efforts to strengthen the national identity in PRAM can be described as follows.

First, in every PRAM routine meeting there is always a two-way interaction from both the management and members. Any ideas can be expressed by both parties. In addition, the ideas in the implementation of the activities were also taken from the input of the public conveyed by citizens through one of the members. This shows the stages of participation in decision making. Second, every PRAM activity involves administrators, members, and public. For example, in blood donor activities, several administrators and members are appointed to be the organizing committee. Blood donation activities were also socialized earlier on whatsapp group social networks to be passed on orally to residents so that public participated in blood donor activities. The activity was carried out well because of the active role of the administrators and members who became the executive committee as well as public who participated as donors. This shows the stages of participation in carrying out activities. Third, after the activities are carried out by PRAM, they are always discussed again in regular meetings to evaluate the activities that has been carried out. Regular meetings are attended by administrators and members who share their opinions on what is good and what aspects need to be improved. This shows the stages of participation in monitoring or evaluation activities. Fourth, the results obtained from the PRAM activities include the more wellknown PRAM, the feeling of happiness from the management, members and public because they can help each other. One of the real results that can be enjoyed by the whole community is the implementation of damaged road repairs by the local village government because previously there were activities to mark the road that was perforated as a form of concern for road users as well as criticism of the 
government to immediately repair the road. This shows the stage of participation in the use of results.

Efforts to strengthen national identity through community participation are closely related to social change because the processes within are related to the emergence of social problems which result in the weakening of national identity. The community seeks to strengthen the national identity by changing the community both members and public to be better than before based on Pancasila. It encourages social engineering. [18] states social engineering is done because of the emergence of social problems. Social problems arise because of a discrepancy between what is supposed to be, what is desired (das sollen) with what becomes reality (das sein). For example, in the context of this research, social media is expected to be able to improve prosocial attitudes, but it turns out that what is expected does not materialize, precisely the opposite, there arises the problem of anti-social behavior. In this research, social engineering is described by identifying the following indicators: 1) the cause of change; 2 ) the agent of change; 3 ) the change targets; 4) the channel of change; and 5) the strategy of change. According to the theory of social engineering, there are several indicators that are suitable for analyzing related efforts made by PRAM to strengthen national identity. The analysis can be described as follows:

\section{The cause of change}

The first step in social engineering that must be done is to determine the cause of the change that is the problem. In connection with this research, the problem that will be changed is to strive to strengthen the national identity through PRAM's participation by making changes among PRAM members. The problems that arise and become the cause of this change are errors of mindset and anti-social attitudes.

\section{The agent of change}

Change agents are individuals, groups or organizations that seek to carry out social engineering. In social engineering of strengthening the national identity through PRAM participation individually, the agent of change is the chairman of PRAM. Meanwhile, the organizational change agents are members of PRAM.

\section{The target of change}

Community members are subject to change because they come from heterogeneous communities that have not previously carried out social activities that can strengthen national identity. Thus, PRAM members are subject to change in order to change their mindset to improve their social caring attitude among others.

\section{The channel of change}

The channels of change that will be passed in social engineering reinforce this national identity through activities carried out by PRAM, namely regular meetings, blood donations, and marking damaged roads.

\section{The strategy of change}

The strategies of change carried out by PRAM include direction, training, assignment and mentoring. The strategy is implemented through various activities which became a channel for change in social engineering to strengthen the national identity through PRAM's participation in Sidomulyo Village.
The first strategy is direction which is a strategy aimed at members, especially to members who are young in PRAM. The second strategy is training, namely the strategy carried out by the management aimed at members who have gone through a briefing phase to be able to practice getting into PRAM activities. The third strategy is the assignment of a strategy aimed at members who are ready to become a committee in PRAM activities such as blood donation, marking perforated roads and other social activities that are not individual. The fourth strategy or the last strategy is mentoring, namely the strategy carried out by the management aimed at members who have been committee members in PRAM activities.

After going through the process in social engineering, the latter is a result of social change. The first result is a change in the mindset of members to do good things to others in their daily lives. The result of the second change is that both the management and members are able to have a high social care attitude. More clearly the social change process of strengthening the national identity through PRAM's participation can be seen in the following scheme.

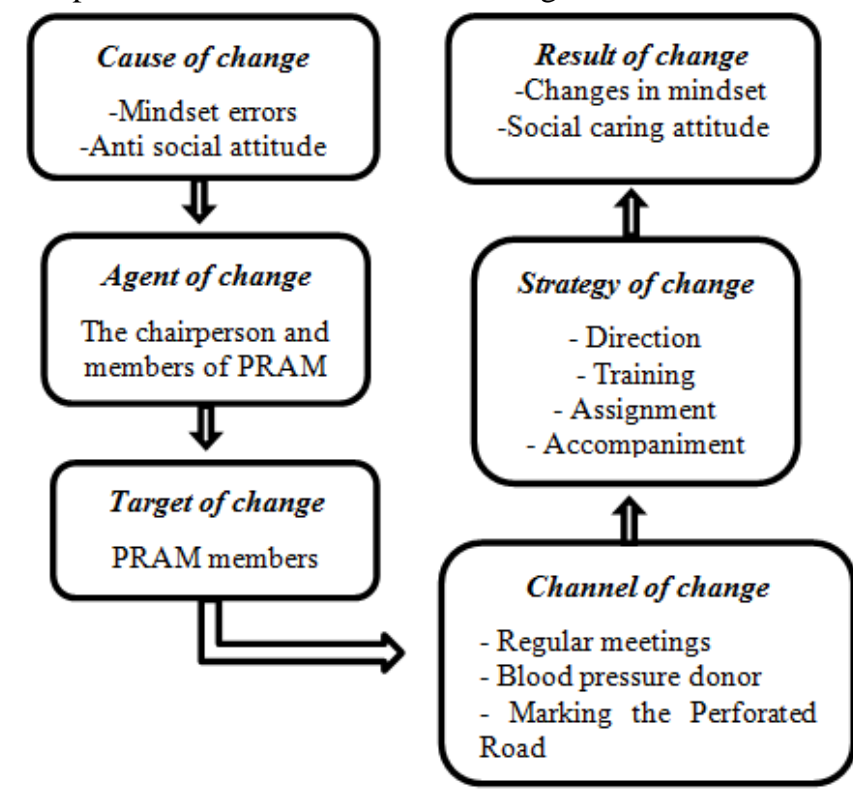

Fig I. Social Engineering Scheme of National Identity Strengthening trough PRAM Participation

The implementation of PRAM activities in an effort to strengthen the national identity experienced several obstacles that could affect the outcome of activities if they were not taken seriously. The results of the research indicated that strengthening the national identity through PRAM participation experienced several obstacles, namely:

\section{A. The Deliberation Process was Hampered}

In every PRAM discussion, many proposals were often different from each other so that the discussion becomes hampered. The differences in the background of each member become a factor in the emergence of various kinds of suggestions in the discussion. This resulted in the difficulties experienced by the leader of the discussion in the 
differences of opinion between the management and members.

\section{B. $\quad$ Licensing Constraints}

Some of the PRAM activities required permission from various parties such as from the village apparatus. Licenses with village officials have encountered problems because there were village officials who did not receive official PRAM posts on social media related social assistance to their citizens.

\section{CONCLUSIONS}

The implementation of strengthening the young generation's national identity in the digital era as an effort to implement Pancasila values in the community was carried out through 3 (three) activities: 1) regular meetings, 2) blood donations, and 3) marking perforated roads. Some of the obstacles faced were the differences in thinking and licensing that were slow. Social changes that occur in PRAM members could change the younger generation from the previous anti-social to have a socially caring attitude that could finally provide good results to strengthen national identity in the current digital era. In addition, efforts to strengthen the young generation's national identity through the internalization of Pancasila values could be used as material for learning PPKn in schools.

\section{REFERENCES}

1. Abdel-Aziz, A. A., Abdel-Salam, H., \& El-Sayad, Z. (2016). The role of ICTs in Creating The New Social Public Place of The Digital Era. Alexandria Engineering Journal, 55(1), 487-493.

2. Alarcón, C. N., Sepúlveda, A. U., Fernández, L. V. \& Lafuente, J. G. (2018). Systematic Mapping on Social Media and Its Relation to Business. European Research on Management and Business Economics, 24, 104-113.

3. Aljawiy, A. Y. \& Muklason, A. (2018). Jejaring Sosial Dan Dampak Bagi Penggunanya. Retrieved from Jurnal Ilmiah Teknologi Program Studi Sistem Informasi Universitas Pesantren Tinggi Darul 'Ulum website: http://www.journal.unipdu.ac.id/ index.php/teknologi/search/searc

4. Betsch, C., \& Iannello, P. (2010). Measuring individual differences in intuitive and deliberate decision making styles: A comparison of different measures (I. A. G. \& C. Witteman, Ed.). London UK: Psychology Press.

5. Budimansyah, D. (2009). Membangun Karakter Bangsa di Tengah Arus Globalisasi dan Gerakan Demokratisasi. Reposisi Peran Pendidikan Kewarganegaran. Bandung Indonesia. Symbolic Meaning of Money, Self-esteem, and Identification with Pancasila Values. International Congress on Interdisciplinary Business and Social Science 2012, 106-115.

7. Kaplan, A.M., \& Haenlein, M. (2010). Users of the World, Unite! The Challenges and Opportunities of Social Media. Business Horizons, 53(1), 59-68.

8. Karabulatova, I. S., Vildanov, K. S., Zinchenko, A. A., Vasilishina, E. N., \& Vassilenko, A. P. (2017). Problems of Identificative Matrices Transformation of Modern Multicultural Persons in the Variative Discourse of Electronic Informative Society Identity. Pertanika Journal Social Science \& Humanities, 25(S), 1-16.

9. Khin, E. W. S. (2009). Women in Accounting Information Systems Research: An Account from Self-
6. Juneman, Meinarno, E. A. \& Rahardjo, W. (2012).

Reflection. Pertanika Journal Social Science \& Humanities, 17(2), 55-63.

10. Kus, Z. (2015). Participation Status of Primary Schoo Students. Global Conference on Contemporary Issues in Education, GLOBE-EDU 2014, 190-196.

11. Lawrence, E. M., Hummer, R. A., Domingue, B. W. \& Harris, K. M. (2018). Wide Educational Disparities in Young Adult Cardiovascular Health. SSM - Population Health, 5, 249-256.

12. Luke, M. A. (2009). Oh the humanity! Humanity-esteem and its social importance. Journal of Research in Personality, 43(4), 586-601.

13. Maarof, N. \& Tan, S. L. (2013). The Effect of Type of Cooperative Learning Grouping on ESL Learners' Reading Comprehension Performance. Pertanika Journal Social Science \& Humanities, 21(4), 1633-1644.

14. Markopoulus, E. (2015). The company democracy model for the development of intellectual human capitalism for shared value. Procedia Manufacturing, 603-610.

15. Nyikes, Z. (2017). Digital Competence and the Safety Awareness Base on The Assesments Results of The Middle East-European Generations. 11th International Conference Interdisciplinarity in Engineering, 916-922.

16. Pachur, T. (2015). Domain-specific preferences for intuition and deliberation in decision making. Journal of Applied Research in Memory and Cognition, (4), 303311.

17. Papulová, Z. \& Papula, J. (2015). Entrepreneurship in the Eyes of the Young Generation. Business Economics and Management 2015 Conference, 514-520.

18. Rakhmat, J. (2000). Rekayasa Sosial: Reformasi, Revolusi, atau Manusia Besar? Bandung: Remaja Rosda Karya.

19. Ramadanty, S. \& Martinus, H. (2018). The Role of Bloggers in Plubic Relations Activities in Indonesia. Pertanika Journal Social Science \& Humanities, 26(T), 263:274.

20. Setiawan, W. (2017). Era Digital dan Tantangannya Seminar Nasional Pendidikan 2017. Sukabumi Indonesia.

21. Sveshnikova, N. (2014). Features of Representatives of Russian Young Generation's Self-attitude. World Conference on Psychology and Sociology 2013, 493498.

22. Theresia, A. (2014). Pembangunan Berbasis Masyarakat. Bandung: Alfabeta.

23. Yudhanegara, F. (2015). Pancasila Sebagai Filter Pengaruh Globalisasi Terhadap Nilai-Nilai Nasionalisme. Jurnal Ilmu Administrasi Negara, 31(2), 165-180.

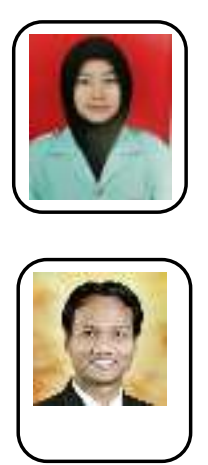

\section{AUTHORS PROFILE}

Nur Fadhilah. A student in Magister of Primary Teacher Education, Sebelas Maret University, Surakarta, Indonesia

Triyanto. Permanent Lecturer in Pancasila and Civic Education Departement, Faculty of Teacher Training and Education, Sebelas Maret University. Civics Doctoral Graduates of Universitas Pendidikan Indonesia - Bandung (2011). Chairperson of the Indonesian Central Java PPKn Professional Association (2012-2017). 2013 Best Lecturers of FKIP UNS. Got MURI Record as Doctor of First Citizenship Education in Indonesia. Get Lesson Study Training in Japan for 1 Month (May-June 2015). International 
International Conference on Recents Advancements in Engineering and Technology (ICRAET-18) |15th and 16th March 2019|Siddhartha Institute of Technology \& Sciences, Telangana, India.

speakers in various countries such as United States, Canada, France, Italy, South Africa, Japan, Australia, China, Hong Kong, Piliphina, Thailand, Singapore, Malaysia, Brunei Darussalam

Rukayah. A lecturer in Primary Teacher Education, Faculty of Teacher Training and Education, Sebelas Maret University. S he has completed his doctoral education at the UNS majoring in Indonesian language education 